\title{
Underwater adhesion: the barnacle way
}

\author{
LIDITA KHANDEPARKER and ARGA CHANDRASHEKHAR ANIL*
}

National Institute of Oceanography, Dona Paula, Goa - 403004

\author{
*Corresponding Author Mailing Address: Dr. A C Anil, Scientist \\ Marine Corrosion and Materials Research Division \\ National Institute of Oceanography \\ Dona Paula, Goa 403 004, INDIA \\ Phone: +91-832-2450404, Fax: +91-832-2450704 \\ Email:acanil@nio.org
}




\title{
Underwater adhesion: the barnacle way
}

\author{
Lidita Khandeparker, Arga Chandrashekhar Anil* \\ National Institute of Oceanography, Dona Paula, Goa - 403004
}

\begin{abstract}
Barnacle cement is an underwater adhesive insoluble protein complex. Marine proteins secreted by the invertebrates such as barnacles and mussels have potential application as powerful adhesives as they insolubilize and adhere to variety of substrates in aqueous environment. The adhesive properties of the barnacle adhesive proteins have been utilized for various dental and medical purposes. These polyphenolic proteins are currently in demand as they are non-toxic biomaterial, highly effective glues and it is very difficult to raise antibodies against these proteins and owing to this low immunogenicity is also attractive for human applications. This review provides a brief account of biochemical composition of barnacle adhesive proteins and their applications.
\end{abstract}

Keywords: A. Phenolic; A. Adhesives; D. Biological adhesion; D. Adhesion by chemical bonding; Barnacle

\footnotetext{
* Corresponding author: email: acanil@nio.org
} 
On immersion of a surface in the marine environment the fouling process is initiated instantly. Biofouling is one of the most serious problems and costs the US Navy an estimated $\$ 1$ billion per annum [1]. In general, the first stage is conditioning of the surface by the adsorption of organic and inorganic compounds. Conditioned surfaces are then colonized by various microorganisms such as bacteria, diatoms etc. [2,3] followed by attachment of algal spores and invertebrate larvae [4]. These biofilms play an important role in mediating settlement and metamorphosis of invertebrate larvae $[5,6,7,8,9,10,11,12,13,14,15,16,17,18,19]$. Chemical cues such as exopolymers and other excreted products produced by microorganisms have been shown to be involved in settlement of macrofoulers, metamorphosis induction, growth and development of organisms $[15,16,20,21,22,23,24,25]$.

\section{Attachment of barnacles}

Among the macrofoulers, barnacles are the dominant fouling organisms found throughout the world. A lot of research on barnacles has been carried out with respect to it's settlement and ecology $[11,12,13,14,15,16,17,20,21,22,23,26,27,28]$.

The larval development of these organisms includes six naupliar instars and a non-feeding presettling cyprid instar. The anatomy of the cyprid is different from the preceding naupliar instars (Figure 1). The cypris larvae explore the substratum hunting a place for attachment [29]. The attaching antennular segment consists of large, thin, circular sucking disc from the edge of which cement is secreted, and the antennular disc becomes attached to the substratum [30,31]. Two types of barnacle adhesion to a substratum have been observed, namely temporary and permanent adhesion [17]. The cyprid employs the antennular disc, an adhesive organ, for temporary attachment to the substratum [32,33] (Figure 2). While exploring a substratum, the barnacle cypris larva leaves behind ' footprints' of temporary adhesive (CTA) 
[34], which is believed to be secreted by the glands of the antennular disc and serves to hold the cyprid onto the substratum while it searches for a place to settle. Barnacle cement is used for permanent settlement and is an underwater adhesive of insoluble protein complex. The cyprid after settling on a surface molts its carapace and the body exoskeleton except for the embedded parts of the antennule and metamorphoses into an adult. The secretion of the cement is most likely linked to the moulting cycle as the cement cells are modified epidermal cells [35].

The barnacle cyprid is discriminating in its choice of settlement site $[36,37,38]$. The capacity to recognize specific molecular configurations by contact was first described for cypris larvae of Balanus balanoides (L.) [37,38]. The laboratory and field studies have demonstrated that barnacle cyprids prefer to metamorphose on or near conspecifics. The settlement pheromone has been recognized as arthropodin or settlement factor ( $\mathrm{SF}+$ ), a glycoprotein present in the adults $[36,38,39]$. A soluble form of arthropodin was reported to be six orders of magnitude more potent than the native glycoprotein [40].

\section{Process of Secretion}

Barnacle cement is recognized as the most durable and toughest connection in the living aquatic world [41]. The cement is secreted by a pair of ovoid or kidney shaped glands (Figure 3), 60-90 $\mu$ thick and $150 \mu$ long which are located behind the compound eyes of cyprids $[31,42]$. If the glands are filled with secretion, the volume of this material would be $471 \mu \mathrm{m}^{3}$ per gland. Each antennule has 20 glands [32,33,34]. Walker examined these glandular structures within the body of larva before and after the cementing of the cyprid to a substratum in order to establish the origin and composition of the cement [43]. He observed the presence of two types of secretory cells in these glands, one of which produces protein 
phenolic compounds and phenolase enzyme whereas the other produces only protein. He further points out through the work of Brown and Pryor $[44,45]$ that

Protein + diphenol $\stackrel{\text { polyphenol oxidase }}{\longrightarrow}$ protein + quinone $=$ tanned protein

Some forms of barnacles possess the basal plate (Balanids) whereas others do not (Cthamalids) (Figure 4). The mode of discharge of secretion from the cells differs among the membrane based and calcareous based barnacles. In the former, there is a series of collecting canals within the cytoplasm of the cement cells (intracellular canals), which join with the larger extracellular cement ducts. Secretion passes into the intracellular canals and is moved along to the larger cement ducts, which have an inner chitin lining. In the later (calcareous base) there are no intracellular collecting canals. Secretions are thought to pass from the cement cells into the cement duct cells directly. The cement duct cells in the calcareous based forms are not chitin lined. The cement, which is initially a fluid of low viscosity, solidifies within a short time after secretion [46]. Stained thin sections of the solidified cement revealed a laminated array of protein matrices surrounded by calcium carbonate (calcite). It has been suggested that the anionic groups on the matric proteins may serve as sites for nucleation during calcification [47]. The disruption in such interactions can thus bring about hindrance during calcification and should be a step ahead.

The adult cement gland appears to develop from the cyprid glands [46] (Figure 5). During the settlement and metamorphosis to the adult stage these glands migrate from their position behind the compound eye of the cyprid to the perimeter of the new bases of the adult perpendicular to the axis symmetry of the body [48]. The larger the basis of the adult barnacle grows, more cement is needed for adhesion, hence new cement glands develop periodically and join the existing ones thus forming a cluster on each side of the mantle [46]. The individual glands of the same cluster are connected by channels with the main channel, which 
in turn conducts the secretion towards the basis. The glands and vesicles are connected by the main channel which are starting points of the separate cement duct networks of different growing periods. Cementing takes place about half way between two consecutive moltings. The basis is cemented so firmly to the substratum by an adhesive substance that the shell will usually break whenever any effort is made to detach the barnacle. This adhesive substance is secreted at the perimeter of the basis and spreads under it to fill any gap between basis and the substratum. In crowded communities, however, barnacles can be displaced by neighboring specimens so that the basis is no longer in contact with the substratum [46].

Properly detached barnacles can be reattached to other surfaces thus indicating that the duct systems connected to these areas are still functional and the passages are still open [46]. In the course of normal development, the new cement does not go beyond the outermost and newest vesicle, because the rest of the main channel and duct network is filled with the flushing fluid, leaving no room for the cement material (Figure 6). The new cement simply pours into the new vesicle and duct network to be secreted at the perimeter. However if the basis separates from the substratum, the cement seal of some duct ends breaks and the flushing fluid drains out of the corresponding ducts and vesicles. A comparison of barnacles grown on non-stick surfaces to those grown on easy-to-attach surfaces revealed differences in the calcified part of the barnacle base as well as in the adhesive's ultrastructure. In contrast to barnacles grown on easy-to-attach substrata, barnacles on non-stick surfaces typically possessed a bell-shaped base plate and a thick multilayered adhesive plaque. This peculiar feature was thought to be a result of downward growth of the parietal plates and subsequent detachment of the weakly adhered base area [49]. The adhesion strength of barnacles was measured during the course of desiccation and it was found that the shear force required to remove barnacles belonging to different genus was different and this was attributed to specific base morphologies [50]. They found that the shear forces required to remove barnacles belonging to genus Balanus 
increased during the course of desiccation up to the point when they suddenly self-detached. The increase was thought to be due to the rising cohesive strength of the adhesive. Growing tensile forces within the weakly cross-linked adhesive, however, are suggested to have led to self-detachment. Whereas, the shear forces required to remove barnacles belonging to genus Elminius were generally low and did not differ significantly during the course of desiccation. The cement secretion was visualized using isolated cement glands from cyprids of Megabalanus rosa and demonstrated the stimulatory effect of dopamine and noradrenaline on such secretion. Their study indicated exocytosis to be the major mode of cement secretion and suggest that gradual, localized exocytotic secretion of cement triggered by catecholaminergic neurons to be the key mechanism during permanent attachment by barnacle cyprids [51].

\section{Properties of barnacle adhesive}

The resistance to chemical breakdown by barnacle adhesive caused a major problem in its characterization. However many investigators have been successful in partially characterizing the barnacle adhesive model proteins of Balanus hameri [52], Balanus nubilus [47], Balanus crenatus [52,53] and B. balanoides [54] which has been synthesized by polycondensation [55]. The alkaline phosphatase activity in the cementing apparatus was found by histoenzymology [56]. Proteins, phenols and polyphenol oxidase (phenolase) were found in both glands and secreted cement of the cyprid [43]. Arvy \& Lacombe demonstrated the presence of succinodehydrogenase in young cement glands [57]. From histochemical [58] and many amino acid analyses $[59,60]$ barnacle cement was shown to contain protein. The barnacle cement harvested in liquid state for polymerization studies reports to contain all the necessary components for self-assembly, progressively changing from a clear liquid to an opaque rubbery insoluble mass [61]. The quinones are absent in the cement of balanid barnacles [60], so the earlier hypothesis suggesting their involvement in a novel cross-link 
[62] is no longer valid. The work detailing advanced analyses of the cement also do not support the involvement of quinones $[63,64]$. The proteins are partially or almost completely soluble in sodium dodecyl sulphate (SDS) containing 2-mercaptoethanol (2-ME) depending on species suggesting that the hydrophobic interactions and sulphur cross-links are responsible in rendering the proteins insoluble $[60,63,64])$. A more common cross-link is strongly implicated, the disulphide bond. However, some cements contain very little cysteine [59] owing to which cross-linking may not be essential for the structural integrity of the matrix, and the hydrophobic interactions abundant in the cement may be equally or more important. The electrophoresis of B. reticulatus cement revealed six major proteins, of which three had molecular weights $>100 \mathrm{kD}$ [64]. One particular protein of $39 \mathrm{kD}$, found in the cement of Balanus perforatus was reported to have the following N-terminal sequence: TYFPVLSYG?SSSLAPVI, where the ? is most likely cysteine [60].

Five major proteins were identified in case of Balanus eburneus using SDS-PAGE and their molecular weights were approximately 7, 22, 36, 52 and $58 \mathrm{kD}$. When 2-ME was used a $\sim 80$ $\mathrm{kD}$ band was also evident. The amino acid composition of the whole cement and 7, 22, 36 and $58 \mathrm{kD}$ proteins revealed high level of Leucine (13.4\%) in bulk composition, along with high levels of Proline $(9.5 \%)$ and Tyrosine $(10.1 \%)$ in case of $36 \mathrm{kD}$ protein, the major protein in the cement [65]. The major protein bands from B. eburneus were also subjected to N-terminal sequencing [65].

B. crenatus cement did not appear to dissolve in guanidine thiocyanate $(2 \mathrm{M})$ even in presence of 2-ME, however, subsequent dialysis of the reaction mixture into water dissolved the cement. The majority of $\mathrm{N}$-terminal sequences of a homologous $38 \mathrm{kD}$ protein from $B$. perforatus [60] bears no similarity to that of $36 \mathrm{kD}$ protein from B. eburneus. However the 
portion of the first six amino acids at the $\mathrm{N}$-terminal is conserved. Barnacle cement matrix is thus a complex mixture of proteins with widely different characteristics [65].

The proteins of secondary cement, which is produced when the barnacle is detached from the substratum in Megabalanus rosa has been characterized [66]. Due to its solubility in aqueous formic acid the cement was fractionated into a soluble fraction, SF1 (21\%); a fraction soluble after reduction, SF2 (37\%); and a fraction insoluble after reduction, IF (42\%). It was found that Sodium dodecyl sulphate Polyacrylamide Gel Electrophoresis (SDS-PAGE) pattern of cyanogen bromide (CB)-peptides from the secondary cement was identical to that of the primary cement produced while the barnacle is attached to the substratum. Recently the cement proteins of M. rosa were separated using reversed-phase High Performance Liquid Chromatography (HPLC) and previously unidentified protein named $20 \mathrm{kDa} M$. rosa cement protein (Mrcp-20k) was found [67]. Its primary structure was revealed by cloning Mrcp-20k cDNA, which was 902 bp long and encoded a 202 amino acid-long open reading frame, including 19 amino acids of the signal sequence. The most common amino acid was Cysteine (17.5\%) followed by Aspartic acid (11.5\%), Glutamic acid (10.4\%) and Histidine (10.4\%). The topology of charged amino acids on the molecular surface is suggested to be maintained by abundant Cys by intramolecular disulphide-bond formation. Thus, although the major portion of barnacle adhesive is mainly protein, the remainder consists of carbohydrate, ash, and trace amounts of lipid [35].

\section{Adhesive strength}

In addition to amino acid composition and molecular weight, the natural barnacle adhesive system operates on different physical factors of the surface. Adhesion is not instantaneous and appears to take a long time. Factors such as increasing adhesive area and enzymic actions 
which oxidize and insolubilize the secreted water-soluble proteins from the glands, must also be considered [55]. The influence of enzymatic actions was considered to prevent adhesion and thus biofouling. It was hypothesized that enzymes of the appropriate specificity may prevent biofouling by hydrolyzing these adhesive polymers. Seventeen commercially available enzyme preparations designed originally for bulk use in a range of end-use applications were tested for their effects on the settlement and/or adhesion of three major fouling species, viz. the green alga Ulva linza, the diatom Navicula perminuta and the barnacle Balanus amphitrite [68]. The serine-proteases were found to have the broadest antifouling potential reducing the adhesion strength of spores and sporelings of $U$. linza, cells of $N$. perminuta and inhibiting settlement of cypris larvae of B. amphitrite.

Understanding of the molecular mechanisms of adhesion, that is bioadhesive bond formation and curing, is essential to develop a more rational approach in designing foulingrelease coatings. Silicone biofouling release coatings have been shown to be an effective method of combating fouling. Barnacle adhesion strength was used to screen seventy-seven polydimethylsiloxane elastomeric coatings for fouling-release properties. Optimum foulingrelease performance was dependent on the interaction of fluid type and elastomeric matrix [69]. Nearly all silicone foul release coatings are augmented with an oil additive to decrease macrofouling attachment strength. The interfacial interaction of the adhesive secreted by the target organism and the coating is also an important determinant of the efficacy of a coating as well as coating attributes such as coating type, incorporated oil type, and the interaction of the coating with the oil $[70,71]$.

The growth of the barnacle B. improvisus on the low elastic modulus, low surface free energy polydimethylsiloxane (PDMS) polymer resulted in the formation of a thick and rubbery barnacle adhesive plaque [72]. When analyzed with tapping-mode atomic force 
microscopy (TM-AFM), the adhesive plaque was shown to be composed of granular morphology with no signs of calcium detected with X-ray photoelectron spectroscopy (XPS), electron probe microanalyzer/energy dispersive spectrometer technique (EPMA/EDS) and Fourier Transform Infrared spectroscopy technique (FT/IR). However, when barnacles were grown on the glassy, high modulus, medium surface free energy PMMA polymer the result was a hard adhesive plaque containing calcium, incorporated as $\mathrm{CaCO}_{3}$, and the granules seemed to have fused together forming a continuous film. The change in barnacle plaque properties as a response to different substrate properties affected the adhesion strength and fracture mechanics during release and suggested to be taken into consideration when designing new innovative fouling-release coatings. A multilayered structure of barnacle adhesive plaque was proposed [73] based on layered modulus regions measured by AFM indentation. The fracture of barnacles from PDMS surfaces was found to include both interfacial and cohesive failure of barnacle adhesive plaque, as determined by protein staining of the substratum after forced barnacle release from the substrate.

An investigation was designed to measure the differences in biofouling and biofouling adhesion strength on three known silicone formulations and an epoxy control at seven static immersion sites located in California, Florida, Hawaii, Hong Kong, India, Italy and Singapore. The study found that whilst the relative performance of the coatings was similar at each site, there were statistically significant differences in the type and intensity of fouling that developed on the coatings and in barnacle adhesion strength among sites. The results emphasize the importance of evaluating potential coatings at more than one static immersion site [74] as barnacle adhesion strength varied with environments. 
A quantitative genetics approach was used to examine variation in the characteristics of the adhesive plaque of the barnacle Balanus amphitrite attached to two silicone substrata. For both materials, significant variation among maternal families in the proportion of barnacles producing a thick adhesive plaque was observed, which suggests the presence of genetic variation, or maternal environmental effects, for this plaque characteristic. The inferences drawn from the study [75] presents the first reported case for potential genetic control of intraspecific phenotypic variation in the physical characteristics and tenacity of the adhesive of a fouling invertebrate.

\section{Application of barnacle adhesive}

Marine proteins secreted by the invertebrates such as mussels and barnacles have potential application as powerful adhesives as they insolubilize and adhere to variety of substrates in a aqueous environment. They provide an example of macroadhesion as they anchor themselves to any solid substrata in marine environment in exchange for habitat advantages. Barnacle cement as well as mussel and clam byssus, all of which are $99 \%$ protein [76] resist enzymatic as well as chemical degradation at ambient temperature. Recently, solutions of $50 \mathrm{vol} \%$ hydrochloric acid in water, and a mixture of water, hydrochloric and formic acids and hydrogen peroxide were used for the barnacle-covered surfaces and the results showed that both treatments dissolved most of the barnacles in $<2$ min at room temperature [77].

The measurement on liquid barnacle adhesive indicated that solids (coatings) with surface free energies lower than 12 dynes $\mathrm{cm}^{-1}$ are needed to prevent attachment [78], hence a low surface free energy approach has been suggested in the control of marine biofouling. Since the introduction of the concept of bioadhesion to the pharmaceutical sciences in 1980's [79,80], the search for bio- and mucoadhesives has become an important issue. Marine biochemists $[81,82]$ have extracted and purified marine adhesive proteins for medical use. 
The adhesive properties of the barnacle adhesive proteins have been utilized for various dental and medical purposes e.g. for repair of bones, nerves and blood vessels in an aqueous environment and dental filling without the need for drilling [83].

It has been suggested that with the advances in biomimetics, future dentin adhesive monomers may contain domains derived from protein-based, underwater bioadhesives secreted by aquatic animals such as mussels and barnacles, making them less dependent on the surface energy of the bonding substrates as well as less susceptible to hydrolytic degradation. Using the concept of controlled release, future adhesives may contain fluorescent biosensors that can detect $\mathrm{pH}$ changes around leaking restorations and may even have the capacity to heal autonomously, in response to microcracks. This ability to self-diagnose and self-repair will increase the life expectancy of adhesive restorations [84].

These polyphenolic proteins are currently in demand as they are non-toxic biomaterial, highly effective glues and it is very difficult to raise antibodies against these proteins and owing to this low immunogenicity is also attractive for human application. Some basic unanswered questions were raised regarding the polyphenolic proteins that are important [85]. How do these proteins interact with different surfaces and other proteins and whether it would be possible to maintain in culture phenol gland cells to produce the polyphenolic proteins? Wiegemann [86] also stated that a synthetic muti-purpose adhesive has not been found so far. Barnacle cement might lead the way to intelligent adhesives that adapt their structures according to the demand such as from gap filling to other structural purposes.

Recently, the adhesive ability of two of the barnacle cement proteins, 36-KD and Mrcp$100 \mathrm{~K}$, was studied using molecular modeling and simulation package GROMACS. This was 
done in order to simulate the behavior of these proteins [87]. On the basis of these simulations it was concluded that hydrogen bonds in proteins play an important role in the protein stability. With this background knowledge, the efforts directed towards more detail understanding of the properties of this adhesive together with the cloning and molecular biology studies would significantly contribute to progress in the basic field and potential applications.

\section{Acknowledgements}

We thank Dr. S.R. Shetye, Director National Institute of Oceanography, Goa for the facilities and encouragement. We thank U. S. Naval Institute for permission to reproduce Figures 14 and 17 from the article "The attachment of macrofouling invertebrates" by Elek Lindner from the book, Marine Biodeterioration: An interdisciplinary study in this review article. We thank 'The Royal Society of London' for granting permission to reproduce the illustration from the article "Structure and function in balanomorph larvae" published in the book Barnacle Biology. We thank the anonymous reviewer's for their suggestions. This is a NIO contribution (\#.....................). 


\section{References}

[1] Callow ME, Callow JE. Biologist 2002;49:4-10.

[2] Marshall KC, Stout R, Mitchell R. J G Microbiol 1971;68:337-48.

[3] Costerton JW, Geesey GG, Cheng K-J. Scientific American 1978;238:86-95.

[4] Wahl M. Mar Ecol Prog Ser 1989;58(1-2):175-89.

[5] Kirchman D, Mitchell R. Ocean 1981;537-41.

[6] Kirchman D, Graham S, Reish D, Mitchell R. J Exp Mar Biol Ecol 1982a;56:153-63.

[7] Kirchman D, Graham S, Reish D, Mitchell R. Mar Biol Lett 1982b;3:131-42.

[8] Kirchman D, Mitchell R. In: Oxley TA, Barry S, editors. Biodeterioration 5. New York: John Wiley \& Sons Ltd, 1983. p. 281-90.

[9] Mitchell R. (1984). In: Marshall KC, editor. Colonization by higher organisms. Germany: Springer-Verlag, Berlin, 1984. p. 189-200.

[10] Mitchell R, Kirchman D. In: Costlow JD, Tipper RC editors. The microbial ecology of marine surfaces. Annapolis, MD: Naval Institute Press, 1984. p. 49-56.

[11] Maki JS, Mitchell R. Bull Mar Sci 1985;37:675-83.

[12] Maki JS, Mitchell R. In: Mirelman D, editor. The function of lectins in interactions among marine bacteria, invertebrates and algae. New York: John Wiley \& Sons, Inc, 1986. p. 409-25.

[13] Mitchell R, Maki JS. In: Thompson M, Sarojini R, Nagabhushanam R editors. Microbial surface films and their influence on larval settlement and metamorphosis in the marine environment. New Delhi, India: Oxford \& IBH Publishing Co, 1988. p. 489-97.

[14] Maki JS, Rittschof D, Costlow JD, Mitchell R. Mar Biol 1988;97:199-206.

[15] Maki JS, Rittschof D, Samuelsson M-O, Szewzyk U, Kjelleberg S, Costlow JD, Mitchell R. Bull Mar Sci 1990;46:499-511.

[16] Maki JS, Rittschof D, Mitchell R. Microb Ecol 1992;23:97-106. 
[17] Maki JS, Yule AB, Rittschof D, Mitchell R. Biofouling 1994;8:121-31.

[18] Rodriguez SR, Riquelme C, Campos EO, Chavez P, Brandan E, Inestrosa NC. Biol Bull 1995;189:272-79.

[19] Khandeparker L, Anil AC, Raghukumar S. J Exp Mar Biol Ecol 2003;289:1-13.

[20] Holmström C, Rittschof D, Kjelleberg S. Appl Environ Microbiol 1992;58:2111-15.

[21] Avelin Mary SR, Vitalina Mary SR, Rittschof D, Nagabhushanam R. J Chem Ecol $1993 ; 19: 2155-67$.

[22] Holmström C, Kjelleberg S. Biofouling 1994;8:147-60.

[23] Holmström C, James S, Egan S, Kjelleberg S. Biofouling 1996;10:251-59.

[24] Keough MJ, Raimondi PT. J Exp Mar Biol Ecol 1996;207:59-68.

[25] Khandeparker L, Anil AC, Raghukumar S. Aquat Microb Ecol 2002a;28:37-54.

[26] Anil AC, Dattesh D, Lidita K. J Exp Mar Biol Ecol 2001;263:125-41.

[27] Dattesh DV, Anil AC. J Exp Mar Biol Ecol 2002;280:117-34.

[28] Khandeparker L, Anil AC, Raghukumar S. J Exp Mar Biol Ecol 2002b;281(1-2):77-88.

[29] Visscher JP. Bull Bur fish 1928;43(2):193-252.

[30] Darwin C. A monograph on the subclass cirripedia- the Lepadidae. London: Ray Society, 1851.

[31] Darwin C. A monograph on the subclass cirripedia- the Banalidae. London: Ray Society, 1854.

[32] Nott JA. Mar Biol 1969;2:248-51.

[33] Nott JA, Foster BA. Phil Trans Roy Soc (B) 1969;256:115-34.

[34] Walker G, Yule AB. J Mar Biol Ass UK 1984;64:679-86.

[35] Walker G. In: Harrison FW, Humes AG, editors. Cirripedia. New York, Chichester: John Wiley, 1999. p. 249-311.

[36] Knight-Jones EW. J Exp Biol 1953;30:584-98. 
[37] Crisp DJ, Meadows PS. Proc R Soc Lond (B) 1962;156:500- 20.

[38] Crisp DJ, Meadows PS. Proc R Soc Lond (B) 1963;158:364-87.

[39] Knight-Jones EW, Crisp DJ. Nature1953;171(4364):1109-10.

[40] Rittschof D. Amer malacol Bull Special Ed 1985;1:111-16.

[41] Abbott A. Sci Progress 1990;74:131-46.

[42] Bernard FJ, Lane CE. J Morphol 1962;110:19-40.

[43] Walker G. Mar Biol 1971;9:205-212.

[44] Brown CH. Nature 1950;165:275.

[45] Pryor MGM. In: Florkin M, Mason HS, editors. Comparative Biochemistry Vol 4B. New York: Academic Press, 1962. p. 371-96.

[46] Lindner E. In: Costlow JD, Tipper RC, editors. The attachment of macrofouling invertebrates. Annapolis MD: US naval Institute, 1984. p. 183-201.

[47] Otness JS, Medcalf DG. Comp Biochem physiol 1972;43B:443-44.

[48] Saroyan JR, Lindner E, Dooley CA, Bleile HR. Ind Engng Chem Prod Res Dev 1970;9(2): 122-33.

[49] Wiegemann M, Watermann B. J Adhes Science Technol 2003;17:1957-77.

[50] Wiegemann M, Watermann B. Biofouling 2004;20(3):147-53.

[51] Okano K, Shimizu K, Satuito CG , Fusetani N. J Exp Biol 1996;199:2131-37.

[52] Walker G. J Mar Biol Ass UK 1972;52:429-35.

[53] Cook M. In: Manly RS, editor. Adhesion in biological systems. New York: Academic Press, 1970. p. 139-50.

[54] Larman VN, Gabbot PA, East J. Comp Biochem Physiol 1982;72B:329-38.

[55] Yamamoto H, Nagai A, Okada T, Nishida A. Mar Chem 1989;26:331-38.

[56] Arvy L, Lacombe D, Shimony T. Am Zool 1968;8:817.

[57] Arvy L, Lacombe D. C R Acad Sci Paris 1968;267:1326-28. 
[58] Walker G. Mar Biol 1970;7:239-48.

[59] Naldrett MJ. Ph D thesis. University of Reading, 1992.

[60] Naldrett MJ. J Mar Biol Ass UK 1993;73:689-702.

[61] Cheung PJ, Ruggieri GD, Nigrelli RF. Mar Biol 1977;43:157-63.

[62] Lindner E, Dooley CA. In: Proceedings of the $3^{\text {rd }}$ International Congress of Marine Corrosion and Fouling, Evanston, IL: Northwestern Univ Press, 1973. p. 653-73.

[63] Barnes H, Blackstock J. J Exp Mar Biol Ecol 1976;25(3):263-71.

[64] Yan W, Pan S. Oceanologia Limnol sin 1981;12:125-32.

[65] Naldrett MJ, Kaplan DL. Mar Biol 1997;127:629-35.

[66] Kamino K, Odo S, Maruyama T. Biol Bull 1996;190(3):403-09.

[67] Kamino K. J Biochem 2001;356(2):503-07.

[68] Pettitt ME, Henry SL, Callow ME, Callow JA, Clare AS. Biofouling 2004;20(6):299311.

[69] Kavanagh CJ, Swain GW, Kovach BS, Stein J, Wood CD, Truby K, Holm E, Montemarano J, Meyer A, Wiebe D. Biofouling 2003; 19 (6):381-390.

[70] Stein J, Truby K, Wood CD, Stein J, Gardner M, Swain GW, Kavanagh CJ, Kovach B, Schultz M, Wiebe D, Holm E, Montemarano J, Wendt D, Smith C, Meyer A. Biofouling 2003;19(Suppl 1):71 - 82.

[71] Truby K, Wood C, Stein J, Cella J, Carpenter J, Kavanagh C, Swain G, Wiebe D, Lapota

D, Meyer A, Holm E, Wendt D, Smith C, Montemarano J. Biofouling 2000;15:141-150.

[72] Berglin M, Gatenholm P. Colloids and Surfaces B: Biointerfaces 2003;28( 2-3):107-117.

[73] Sun Y, Guo S, Walker G, Kavanagh CJ, Swain GW. Biofouling 2004;20 (6):279 - 289.

[74] Swain G, Anil AC, Baier RE, Chia F -S, Conte E, Cook A, Hadfield M, Haslbeck E, Holm E, Kavanagh C, Kohrs D, Kovach B, Lee C, Mazzella L, Meyer AE, Qian P-Y, Sawant 
SS, Schultz M, Sigurdsson J, Smith C, Soo L, Terlizzi A, Wagh AB, Zimmerman R, Zupo V. Biofouling 2000;16(2-4):331-34.

[75] Holm ER, Orihuela B, Kavanagh CJ, Rittschof D. Biofouling 2005;21(2):121-26.

[76] Kaleem K, Chertok F, Erhan S. Nature 1987;325(6102):328-29.

[77] Dolez PI, Love BJ. Int J Adh Adhesives 2002;22 (4):297-301.

[78] Lindner E. Biofouling 1992;6:193-205.

[79] Gurny RE, Junginger HE. Bioadhesion Possibilities and future trends. Wiss

Verlagsgesellschaft, Stuttgart, 1990.

[80] Lenaerts VM, Gurny RE. Bioadhesive drug delivery systems. Cleveland: CRC Press, 1990.

[81] Waite JH. J Biol Chem 1983;258:2911-15.

[82] Waite JH. Int J Adhesion adhesives (1987)7:9-14.

[83] U S Patent 4585585. Decapeptides produced from bioadhesive polyphenolic proteins, 1986.

[84] Tay FR, Pashley DH. J Adhesiv dentistry 2002;4(2):91-103.

[85] Burzio LO, Burzio VA, Silva T, Burzio LA, Pardo J. Current Opinion in Biotech 1997;8(3):309-12.

[86] Weigemann M. Aquat Sci 2005;67:166-76.

[87] Yin J, Zhao Y-P, Zhu R-J. Mater Sci Eng A 2005;409:160-166. 


\section{FIGURE LEGENDS}

FIGURE 1 Life cycle of barnacle showing six naupliar instars and a non-feeding, pre-settling cyprid instar that settle and metamorphose into an adult.

FIGURE 2 Cypris antennule showing segments I-IV with attachment organ (a.o.) on third segment, a.c.d. - axial cement duct, a.s. - axial sensory seta, s.t.s - subterminal setae, t.s terminal setae; Source: Walker G, Yule A. B. and Nott J. A. 1987, Barnacle biology: Crustacean Issues 5, Balkema A. A., Rotterdam. (Cross referred from: Nott and Foster, 1969).

FIGURE 3 Barnacle cement gland.

FIGURE 4 (a) Ventral view of barnacle showing a basal plate (b) Ventral view of barnacle without a basal plate.

FIGURE 5 Metamorphosis of cyprid to adult barnacle, showing the migration of the cyprid cement glands to the position in which they are retained and function in the adult; Source: Lindner E 1984, Marine Biodeterioration: an interdisciplinary study: The attachment of macrofouling invertebrates, eds Costlow, J. D. and Tipper, R. C., US naval Institute, Annapolis MD.

FIGURE 6 A: Secretion of cement from cement gland to newest vesicle and duct network during normal development; B: Flushing of duct network following cement secretion; C: Secretion of cement when a separation from substratum has occurred in the region of an old duct; Source: Lindner E 1984, Marine Biodeterioration: an interdisciplinary study: The attachment of macrofouling invertebrates, eds Costlow, J. D. and Tipper, R. C., US naval Institute, Annapolis MD. 


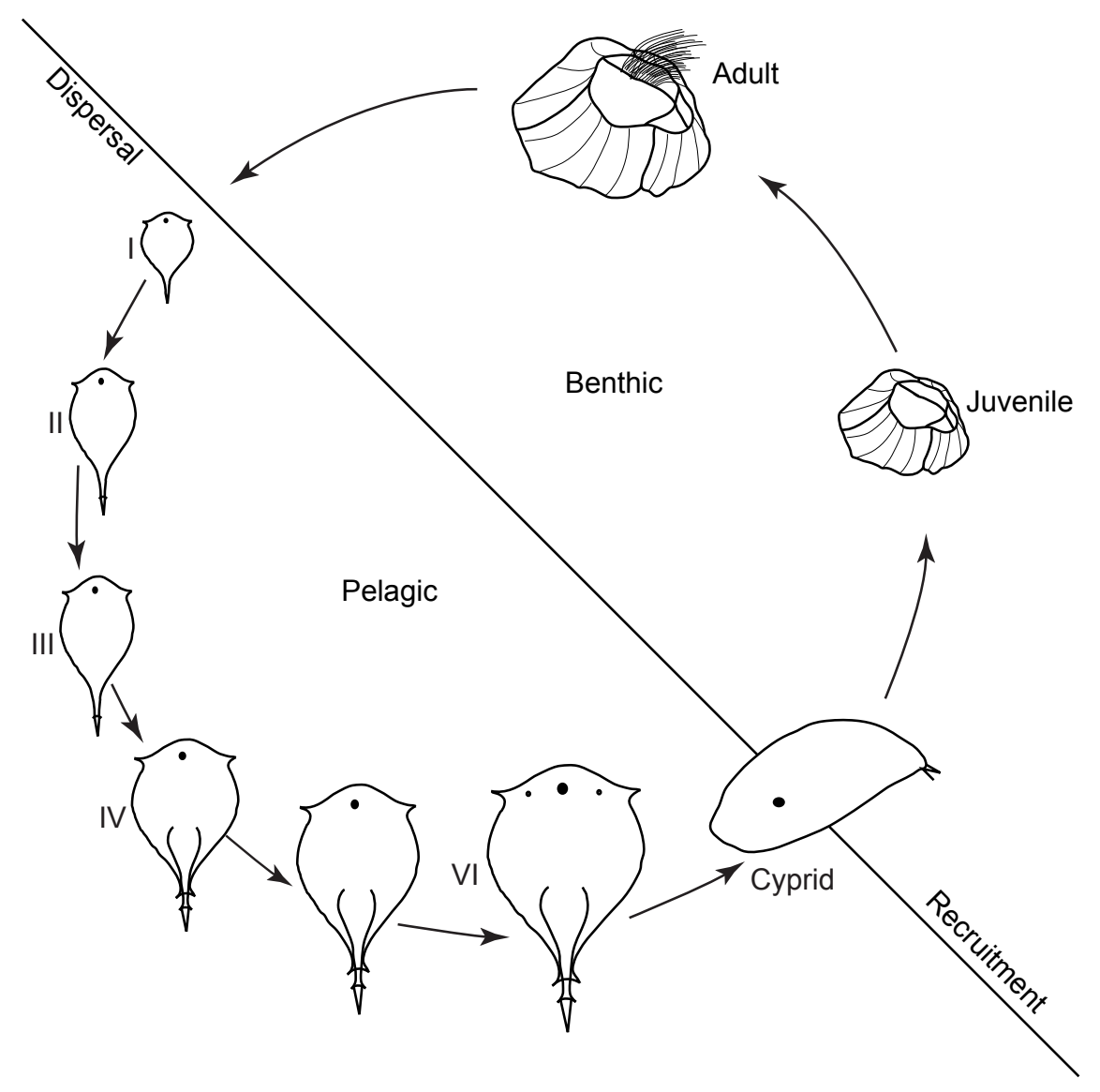

Figure 1

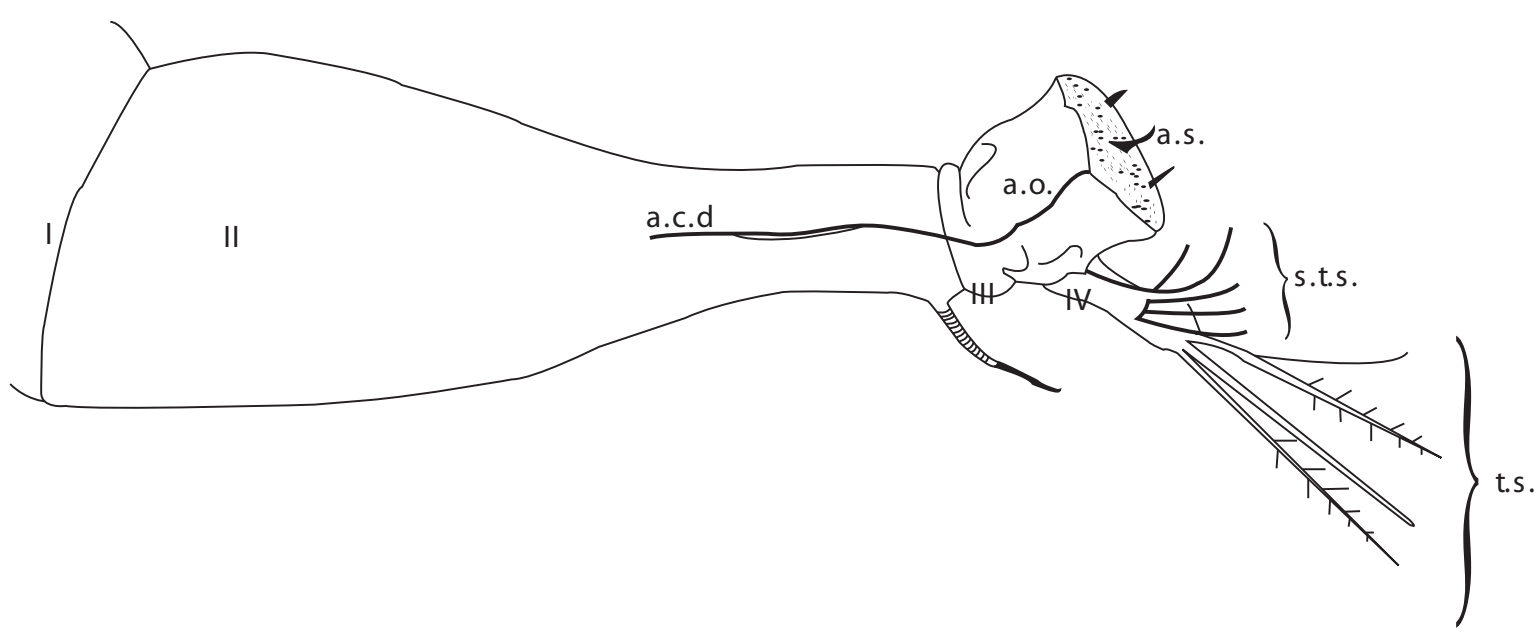

Figure 2 


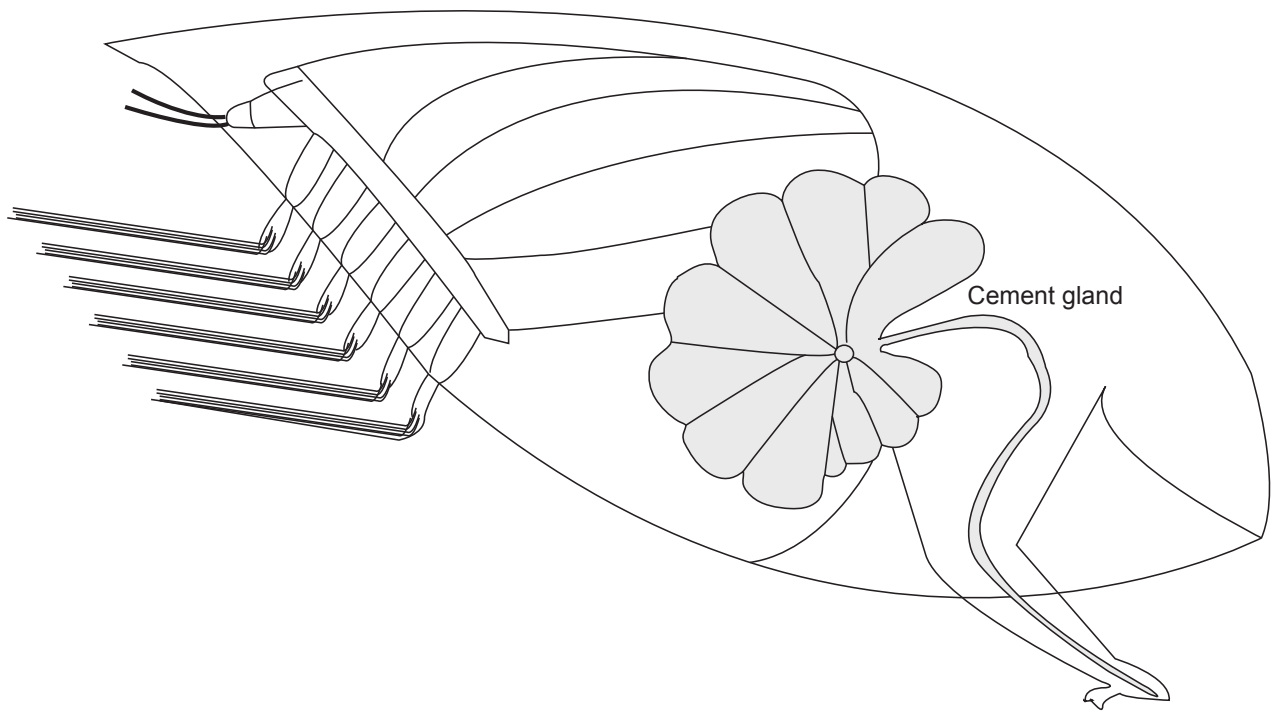

Figure 3

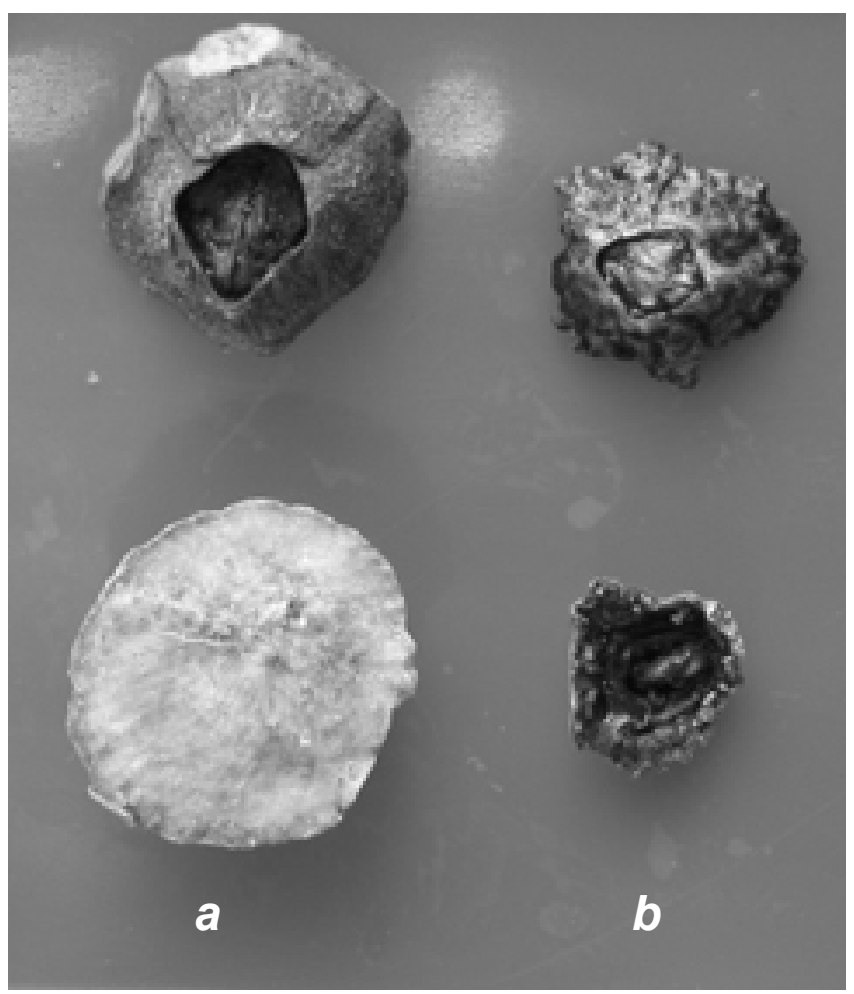

Figure 4 


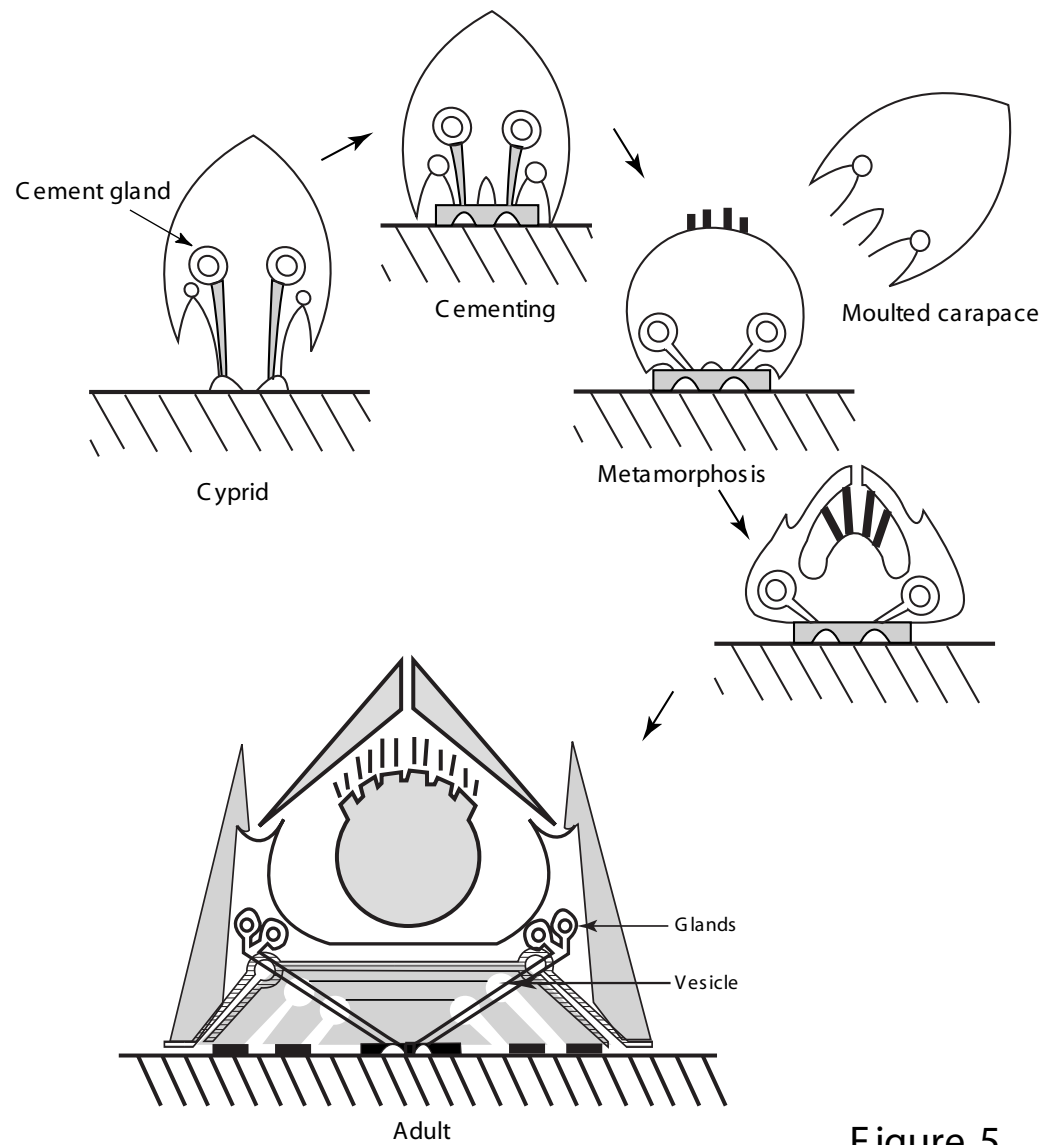

Figure 5
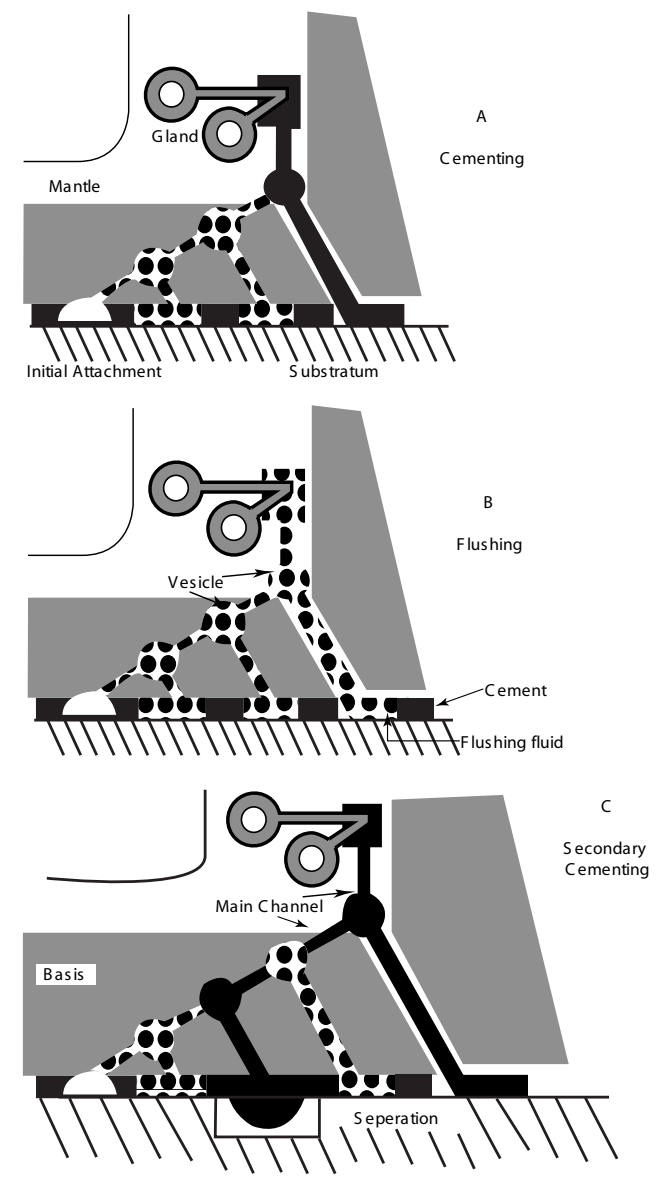

Figure 6 